\title{
RUSUN PEKERJA MIGAS
}

\author{
Defri Hardi Kurniawan ${ }^{1}$, Agus Basri Saptono ${ }^{2}$, Benny Hermawan ${ }^{3}$ \\ defri.hardi15@gmail.com, abas140871@yahoo.co.id. \\ (1),(2),(3) Program Studi Arsitektur, Fakultas Teknik, Universitas Lancang Kuning \\ Jl. Yos Sudarso km. 8 Rumbai, Pekanbaru, Telp. (0761) 52324
}

\begin{abstract}
ABSTRAK
Pemukiman dan perumahan merupakan kebutuhan utama/primer yang harus dipenuhi oleh manusia. Perumahan dan pemukiman tidak hanya dapat dilihat sebagai sarana kebutuhan hidup, tetapi lebih jauh adalah proses bermukim manusia dalam rangka menciptakan suatu tatanan hidup untuk masyarakat dan dirinya dalam menampakkan jati diri. Dilihat dari kondisi perkembangan permukiman di Kota Duri sampai saat ini masih banyaknya warga atau masyarakat yang bekerja di perusahaan migas yang masih belum memiliki suatu hunian yang dapat memenuhi kebutuhan hunian pekerja tersebut, sehingga banyak dari masyarakat bermukim di daerah yang jauh dari area kawasan industrial migas.

berhubungan dengan hal tersebut dibutuhkan perencanaan Rusun dengan pendekatan arsitektur perilaku yang bertujuan untuk menciptakan kenyamanan dan fungsional yang berlandaskan fungsi bangunan sebagai tempat tinggal.
\end{abstract}

Kata Kunci: Rusun Pekerja Migas

\begin{abstract}
Settlements and housing are the primary / primary needs that must be met by humans. Housing and settlements can not only be seen as a means of living, but further a process of living in a framework of human life in order to create a living order for the community and itself in revealing identity. Judging from the conditions of settlement development in the City of Duri, there are still many people or communities working in oil and gas companies that still do not have a residence that can meet the occupancy needs of the workers, so that many of the people live in areas far from the oil and gas industrial area.

In relation to this, it is necessary to arrange Flat Plan with an architectural behavior approach that aims to create comfort and functionality based on the function of the building as a place to live.
\end{abstract}

Keywords: flats Oil and Gas Workers

\section{PENDAHULUAN}

Rumah atau tempat tinggal merupakan salah satu kebutuhan dasar bagi manusia (primer) disamping kebutuhan sandang dan pangan. Dikatakan sebagai kebutuhan dasar (basic human needs) karena merupakan unsur yang harus dipenuhi guna menjamin kelangsungan hidup manusia. Dimana kebutuhan dasar ini akan menentukan taraf kesejahteraan sekaligus kualitas hidup manusia itu sendiri karena itu suatu hunian pada hakekatnya dapat berpengaruh terhadap kualitas kehidupan orangorang yang tinggal didalamnya.Seiring dengan perkembangannya kota-kota besar di Indonesia dalam usaha penyediaan hunian bagi warganya kerap dihadapkan dengan permasalahanpermasalahan. Bertambahnya penduduk kota disebabkan karena kelahiran maupun urbanisasi yang tidak diimbangi dengan daya tampung kota. Sehingga menyebabkan ketidak teraturan pada tata ruang kota dan dapat menumbuhkan kawasan atau permukiman padat penduduk, kumuh dan cenderung liar. Keadaan seperti ini juga tengah dialami pada kota-kota di daerah riau seperti:

\section{Kota Pekanbaru \\ Kota Batam \\ Kota Siak \\ Kota Duri}

Kota Duri sebagai Kota penghasil minyak terbesar di Indonesia memiliki luas 937,47 $\mathrm{Km}^{2}$ dengan jumlah kependudukan yang cukup tinggi. Secara rinci, Jumlah penduduk di kecamatan Mandau hingga bulan April tahun 2016 sudah mencapai 274.179 jiwa.

Melihat dari kondisi perkembangan permukiman di Kota Duri sampai saat ini masih banyaknya warga atau masyarakat yang bekerja di perusahaan migas yang masih belum memiliki 
suatu hunian yang dapat memenuhi kebutuhan hunian pekerja tersebut, sehingga banyak dari masyarakat bermukim di daerah yang jauh dari area kawasan industrial migas.

\section{METODE PENELITIAN}

Metode yang digunakan untuk memperoleh data-data yang diperlukan untuk perancangan Rusun Pekerja Migas di Duri antara lain :

\subsection{Studi Literatur}

Mencari literatur, baik yang berupa buku tugas akhir, teks, makalah, jurnal, laporan seminar, artikel dan majalah untuk pemahaman yang lebih mendalam mengenai pokok perancangan yang diambil.

\subsection{Survey Lapangan}

Langsung melakukan peninjauan dan pengamatan pada lokasi yang akan di jadikan obyek perancangan, mengambil data langsung berupa foto.

\subsection{Wawancara}

Mendapatkan informasi yang di butuhkan secara langsung dengan cara mengajukan beberapa pertanyaan kepada pihak yang terkait yang berhubungan dengan judul tugas seminar arsitektur.

\section{HASIL DAN PEMBAHASAN}

Lokasi tapak berada di Jalan Kulim Km 6, Kecamatan Mandau, Kota Duri, Luas tapak yang direncanakan sekitar $\pm 14.410 \mathrm{~m} 2$.

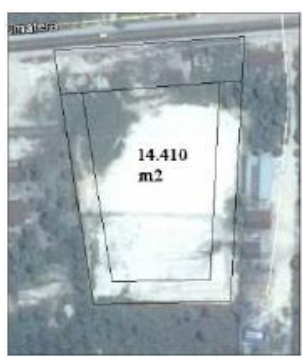

Gambar 1. Tapak Rusun Pekerja Migas

\subsection{Akses Jalan di Sekitar Tapak}

Lokasi "Rusun Pekerja Migas" ini dapat di akses oleh kendaraan roda dua, mobil dan kendaraan umum. Lokasi yang langsung berhadapan dengan jalan utama atau jalan lintas Sumatra.

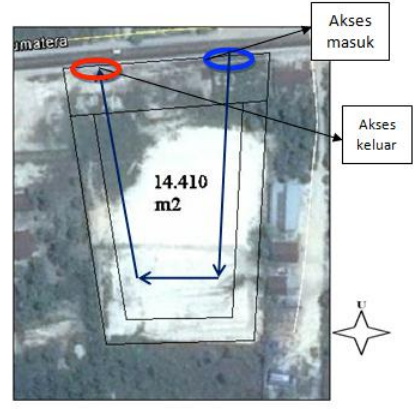

Gambar 2. Jl.Kulim Km 6

\subsection{Kondisi Dalam Tapak}

Kondisi di dalam tapak berupa lahan kosong, dengan jenis tanah yaitu tanah keras

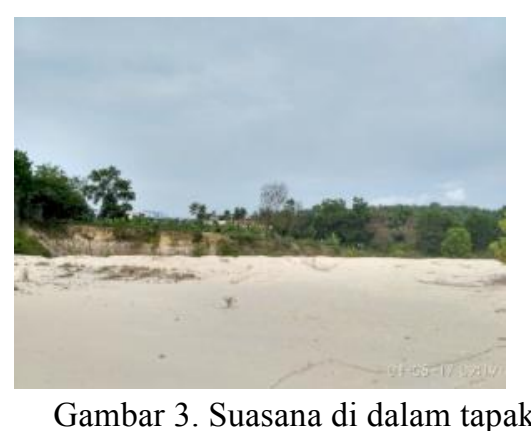

\subsection{Apek Manusia}

Manusia merupakan faktor dasar dan penting yang harus difikirkan oleh perancang, karena bangunan direncanakan untuk memenuhi kebutuhan manusia dan kriteria penggunanya. Pada faktor manusia ini terdapat 3 aspek yang sangat penting, yaitu :

1. Pengunabangunan (PelakuKegiatan).

2. Kegiatan akan dilakukan oleh pengguna bangunan (aktifitas Pelaku).

3. Kebutuhan pengguna bangunan (kebutuhan Ruang).

\subsection{Analisis Pelaku Kegiatan}

Pelaku kegiatan yang ada pada bangunan "Rusun Pekerja Migas" adalah sebagai berikut:

\subsubsection{Penghuni}

Penghuni yang bertetap di suatu perusahaan migas.

a. Pekerja bawah

- Buruh (labourer): memuat, memindahkan, dll.

- Pembantu peledakan (blast helper): membantu mengisi bahan peledak kedalam lubang tembak 
- Pembantu pengebor (drillers assistant): membantu mengoperasikan /memindahkan alat bor

- Pemakai peralatan (equipment operator): mengendarai doser, grader, truck

- Pembantu montir (mechanics helper): membantu membersihkan, minyak, dan menguji serta memperbaiki peralatan

- Pembantu kelistrikan (electricians helper): membantu memasang kabel, mengecek dan memperbaiki peralatan kelistrikan.

\subsubsection{Pengelola}

Pengelola adalah orang yang terlibat dalam pengurusan dalam struktur organisasi di bangunan ini yaitu :

- manager

- Sekretsris

- Kepala pengelola

- recepsinis

- petugas ADM

- Petugas Kebersihan

- Security

\subsubsection{Pengunjung}

Pengunjung adalah keluarga dan kerabat dekat staf pengeboran.

\subsection{Analisis Site}

Lokasi Site Pekanbaru Indoor Recreation Centre berlokasi di Jalan Tuanku Tambusai, Kecamatan Tampan, Kota Pekanbaru, Provinsi Riau.

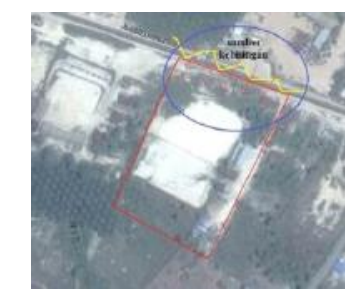

Gambar 4. Analisis Site

\subsection{Dimensi Site}

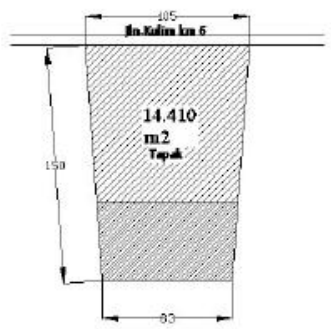

Gambar 5. Dimensi Site

\subsection{Batasan-Batasan Dimensi Site}

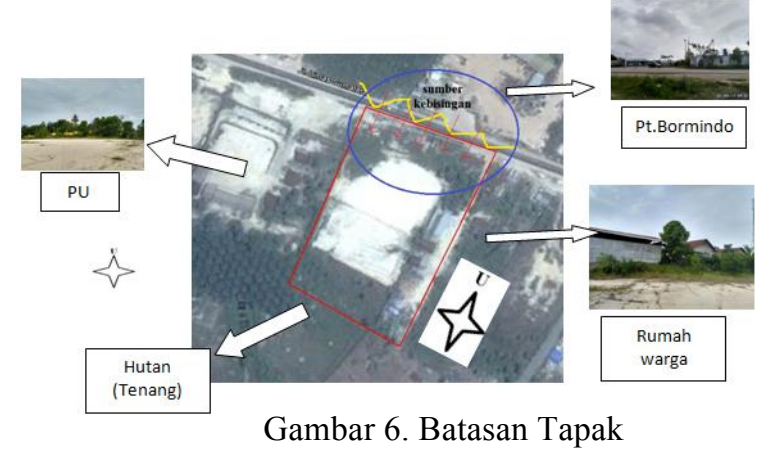

View paling menonjol yaitu pada bagian Utara. Karena pada bagian ini view langsung mengarah ke Jalan utama pada bagian ini merupakan view yang paling mudah di akses. Karena pengguna bangunan memerlukan akses yang mudah di capai.

\subsection{Analisis Tapak}

Perencanaan "Rusun Pekerja Migas" diharapkan dapat menjadi salah satu tempat Hunian yang dapat ditempati bagi pekerja migas. Oleh karena itu lokasi terpilih berada di jalan Kulim km 6. Kondisi eksisting berupa tanah keras.

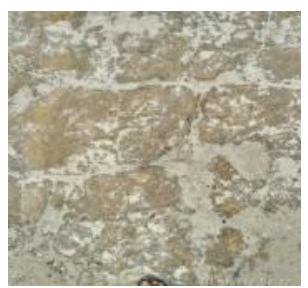

Gambar 7 . Kondisi Tanah

\subsection{Analisis Dari Luar Kedalam Tapak}

Pada gambar berikut merupakan suasana atau pendangan yang diambil dari view luar kedalam site.

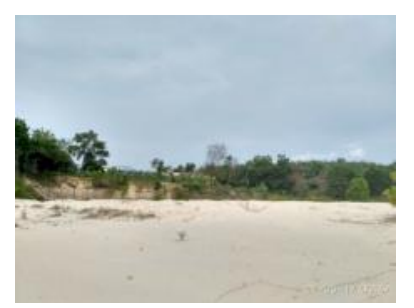

Gambar 8 . View dari luar site 


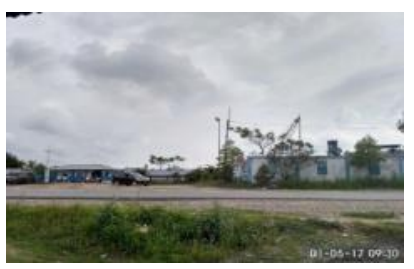

Gambar 9. View dari dalam site

\subsection{Analisis Orientasi Matahari}

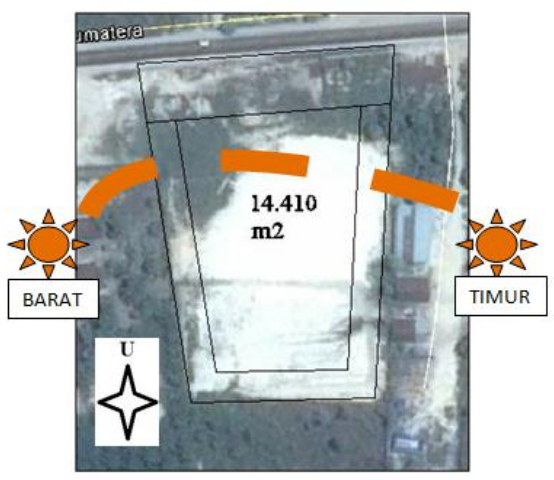

Gambar 10. Orientasi matahari

Dari analisis orientasi matahari terhadap tapak bahwasanya pengelompokan kegiatankegiatan yang nyaman terhadap kondisi tapak ialah berorientasi ke utara karena berdekatan dengan jalan utama.

\subsection{Analisis Pencapaian Dan Sirkulasi}

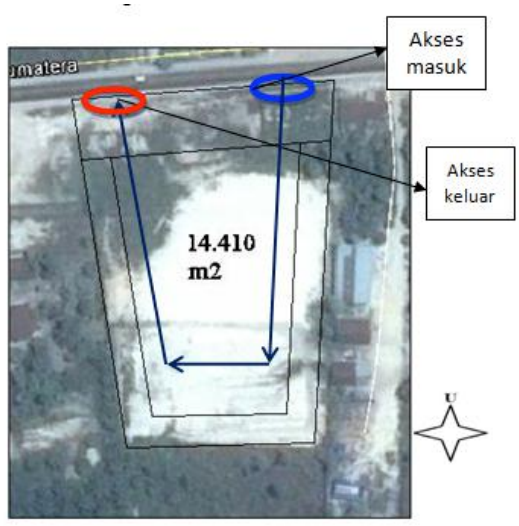

Gambar 11. pencapaian dan sirkulasi

Lokasi "Rusun Pekerja Migas" ini dapat di akses oleh kendaraan roda dua, mobil dan kendaraan umum. Lokasi yang langsung berhadapan dengan jalan utama atau jalan lintas Sumatra.

\subsection{Analisis View Dan Kebisingan}

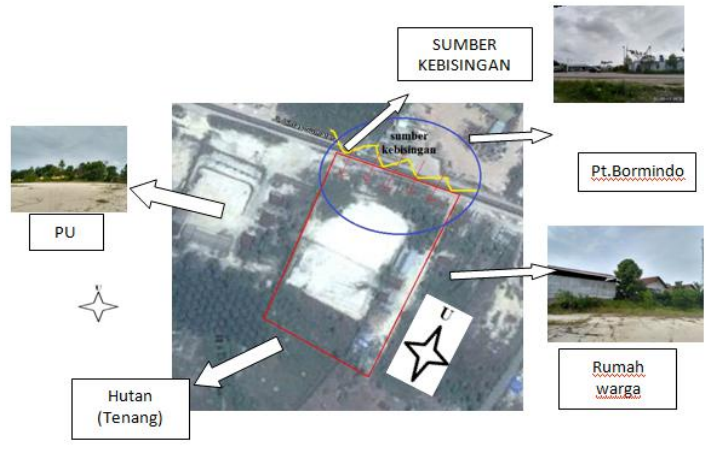

Gambar 12. view dan kebisingan

Pada lokasi ini sumber kebisingan paling tinggi berada di Jl. Kulim km6. Hal ini dikarenakan karena jalan tersebut merupan jalan utama yang banyak dilalui oleh kendaraan.

Untuk mengurangi kebisingan akibat kendaraan bermotor, sebagai solusi desain dari hal ini maka di lakukan:

a. Penanaman pohon dan tanaman peredu sebagai buffer hidup yang dapat mengurangi tingkat kebisingan sekaligus polusi udara.

b. Zoning ruang yang sensitif terhadap kebisingan di jahukan dari sumber kebisingan.

\subsection{Penzoningan Tapak}

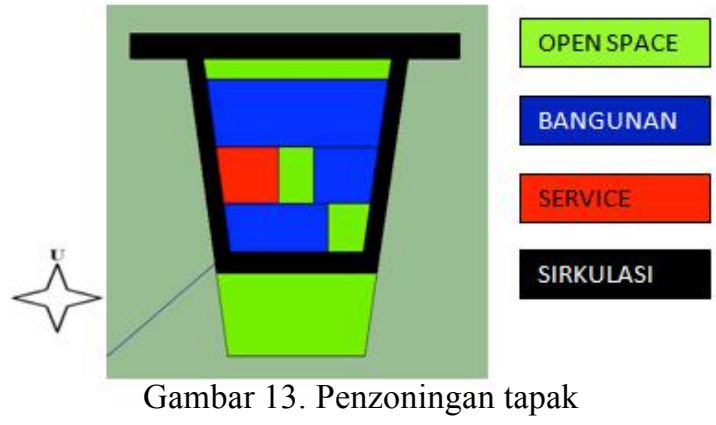

Perletakan zoning pada site didasarkan atas orientasi arah sinar matahari dari timur ke barat pada masa bangunan, selain pertimbangan karena orientasi arah sinar matahari untuk peletakan arah orientasi bangunan mengahadap ke arah Jl. Kulim km6. Untuk peletakan parkir terdapat di sisi barat agar akses kendaraan mudah di capai bagi pengguna bangunan.

\subsection{Analisis Intesitas Bangunan}

Analisis intensitas bangunan ini adalah ketentuan teknisi mengenai kepadatan dan ketinggian bangunan yang di persyaratkan pada lokasi untuk kawasan tertentu, yang meliputi koefisien dasar bangunan (KDB), koefisien lantai bangunan (KLB), dan jumlah lantai bangunan. 
Untuk persyaratan lokasi yang berada di wilayah Kota duri, tepatnya terletak di Jl.Kulim km 6 sebagai berikut :

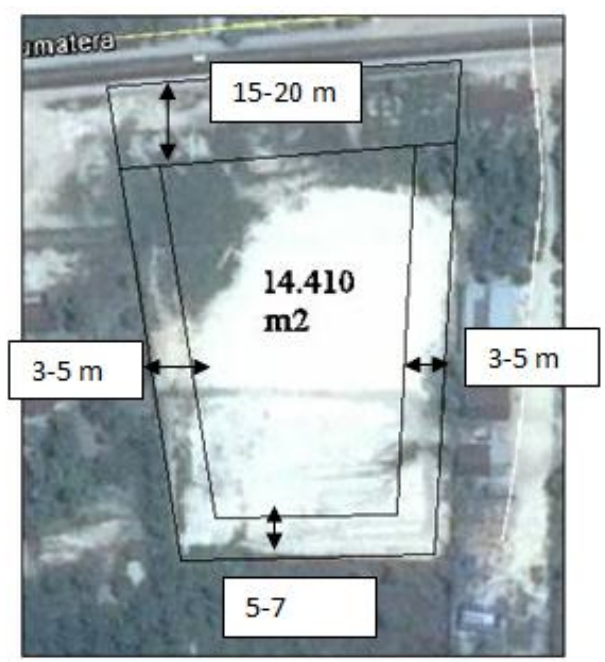

Gambar 14. Intensitas bangunan

KDB : $60 \%$

KLB : 3.00

GSB : 15-20 (muka), 5-7 (belakang),3-5

(samping)

Ketinggian bangunan : 2-5 lantai

Luas : $14.410 \mathrm{~m}^{2}$

- Luas Lantai Dasar yang diizinkan :

KDB x L.Lahan

$60 \% \times 14.410 \mathrm{~m}^{2}$

$=8646 \mathrm{~m}^{2}$

- Luas Lantai Bangunan yang diizinkan :

KLB x L. Lahan

$3.00 \times 14.410 \mathrm{~m}^{2}$

$=43.230 \mathrm{~m}^{2}$

\subsection{Analisis Vegetasi}

Pola tata hijau ditentukan sebagai elemen pendukung untuk memperindah site dan juga dapat menciptakan suasana iklim yang sejuk serta dapat melindungi bangunan dari sengatan sinar matahari. Vegetasi juga bertujuan untuk sebagai pemecah angin dan penghawaan alami.

\subsection{Konsep Dasar Perancangan}

Prinsip perancangan arsitektur nantinya akan di sesuaikan dengan beberapa analisis, yaitu :

1. Orientasi dan konfigurasi bangunan di sesuaikan dengan potensi lingkungan dan keterkaitannya dengan teori - teori perilaku sebelumnya.

2. Fasad bangunan mengikuti fungsi dan pola prilaku yang berasal dari pengamatan perilaku Pekerja.
3. Zona, perogram ruang dan fasilitas di desain sesuai dari pengamatan perilaku Pekerja di dalam bangunan.

4. Tingkat kenyamanan di buat konsisten.

\subsection{Konsep Zoning Tapak}

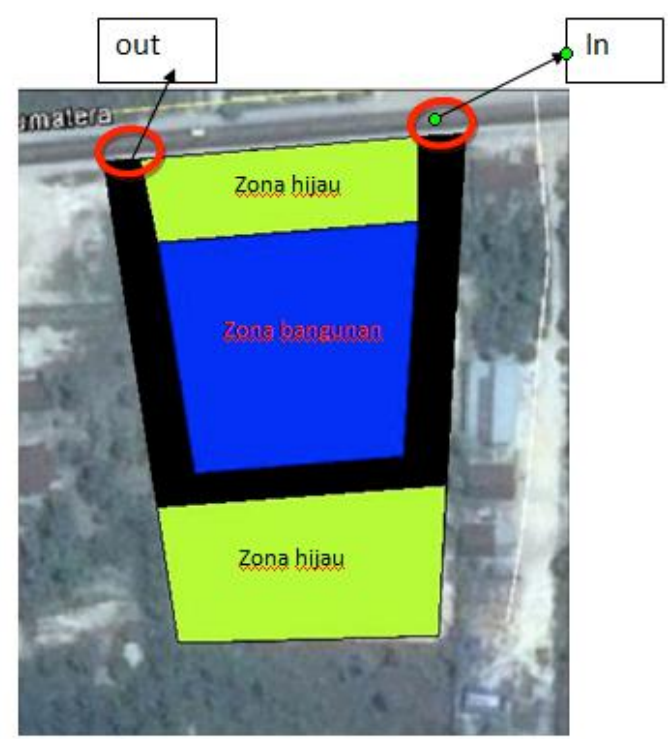

Gambar 15. Zoning tapak

Pada konsep zoning tapak bangunan mengikuti bentuk pola tapak dan merespon tapak. Bangunan terdapat open space atau ruang terbuka yang berada di belakang bangunan. Dalam hal ini ruang terbuka berupa taman dan fasilitas lainnya, ruang terbuka selain berfungsi sebagai penyaring dari kondisi alam yang beriklim tropis juga berfungsi sebagai ruang untuk bersantai, dan juga berfungsi sebagai sarana olahraga dan untuk berinteraksi dan bersosialisasi antar pengguna bangunan.

\subsection{Konsep Sirkulasi}

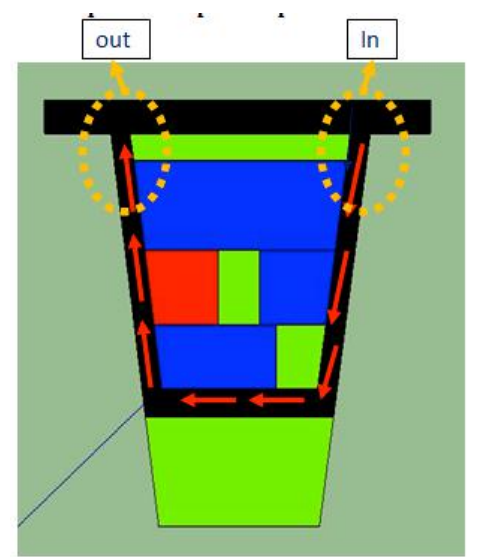
Akses masuk di letakan di area jalan. Protokol agar memudahkan menuiy bangunan

Gambar 15. Konsep Sirkulasi 
Posisi pintu masuk kedalam site di letakkan di sisi utara site karena berdekatan dengan jalan utama. Dan jalur kendaran ini menggunakan jalur tunggal yang lebar,di karenkan bangunan ini adalah rumah tinggal yang mengutamakan keamaan dan hanya memiliki 1 akses masuk ke dalam tapak

Dalam konsep sirkulasi pada Rusun ini di bagi menjadi 2 bagian yaitu :

\section{a. Sirkulasi Ruang Luar}

Dalam konsep sirkulasi ruang luar ini dapat di bagi menjadi 2 jenis yaitu :

1. Ruang luar aktif adalah ruang luar yang menampung kegiatan manusia meliputi parkir dan sirkulasi kendaraan. adapun bentuk pola parkir yang digunakan ialah parkir 90 derajat.

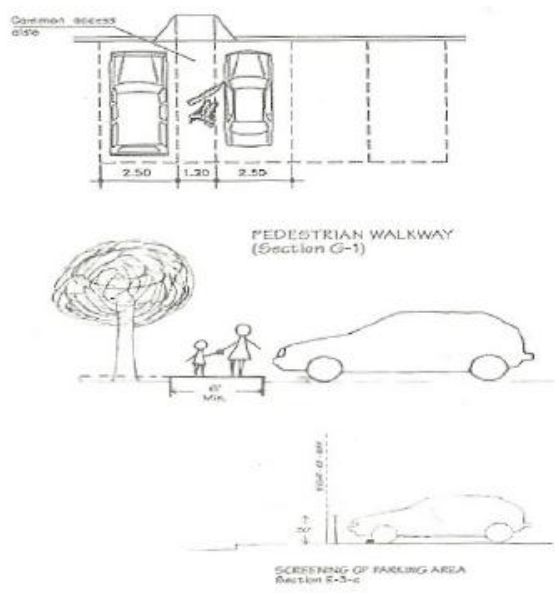

Gambar 16. Konsep Parkir

2. Ruang Luar Pasif berupa Elemen ruang luar yang direncanakan sebagai unsur pembentuk ruang-ruang positif. Ruang positif yang terjadi disini berperan sebagai ruang terbuka bagi

3. lingkungan, adapun macam macam bagian elemen ruang luar ialah akses pejalan kaki dan taman / area hijau.

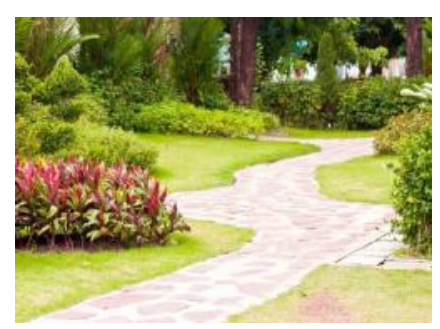

Gambar 17. Konsep Ruang Luar

\section{b. Sirkulasi ruang dalam}

Pada pola sirkulasi ruang dalam di Rehabilitasi ini menggunakan konsep sirkulasi pencapaian langsung, dengan menggunakan konsep pencapaian langsung ini maka penghuni langsung menuju unit hunian, di karenakan si penghuni yang lelah bekerja.

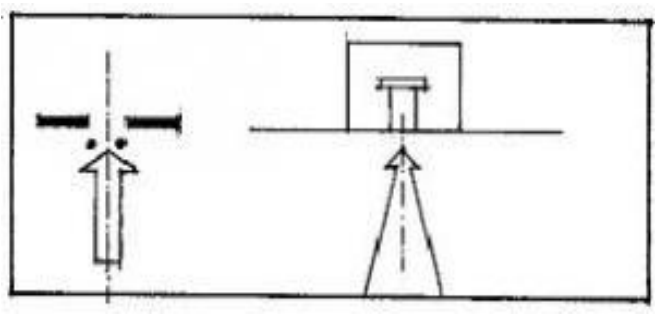

Gambar 18. Konsep Sirkulasi langsung

\subsection{Konsep Struktur}

1. Sub Struktur

Pondasi yang akan digunakan yaitu pondasi bor pile /strauss pile dan cor beton bertulang, karena banguna lebih dari 3 tingkat. Mengunakan pondasi bor pile/strauss pile disesuaikan dengan kondisi bangunan setempat Dari segi metode pembangunan, bor pile/strauss pile lebih cepat dan mudah jika dibandingkan dengan pondasi-pondasi lainnya.

2. Middle Struktur

a. Struktur Horizontal

Merupakan sistem struktur balok dan plat lantai. Penerapan sistem stuktur seperti ini dapat diterapkan pada bangunan bentang lebar dan sedang. Pelaksanaan yang mudah dan ekonomis dari segi material dan biaya.

b. Struktur Vertical

Untuk struktur vertical digunakan struktur kolom yang kuat menahan gaya lateral, karena bangunan direncanakan lebih dari 1 lantai.

3. Up Struktur

Pada sistem struktur penutup bangunan atau atap, dalam hal ini bangunan akan menggunakan struktur rangka atap kombinasi. Yaitu dengan rangka baja ringan (spaceframe) dan atap dak beton bertulang. Struktur kombinasi rangka baja ringan dan dak beton bertulang dengan atap penutup metal aluminium juga dapat di ekspresikan sebagai roof garden ( taman atap ). 


\section{Konsep Utilitas}

- $\quad$ Sistem Air Bersih
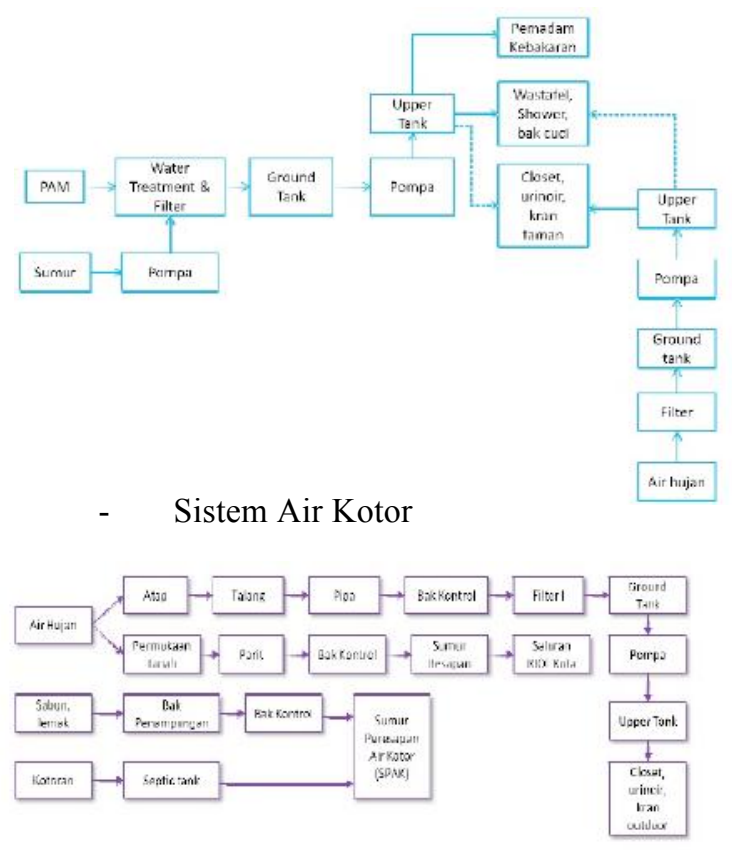

- $\quad$ Sistem Jaringan Listrik

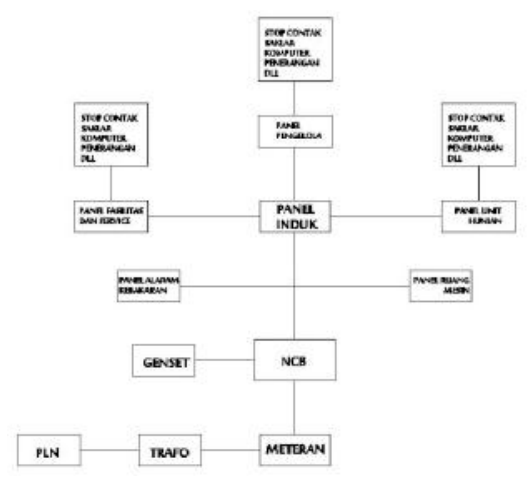

\subsection{Konsep Massa Bangunan}

Bentuk dasar massa bangunan ini adalah persegi panjang dan tranformasinya dengan mempertimbangkan fungsi, tapak, lingkungan sekitar dan perilaku pengguna bangunan serba instan. Juga sebagai tindakan efisiensi bentuk (ekonomis dan efektif),

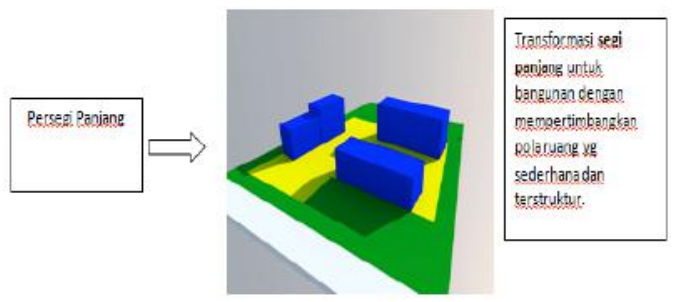

Gambar 19. Konsep Massa bangunan
Bentuk dasar massa bangunan adalah persegi Panjang, dan merupakan simbol kesederhanaan, dan juga membentuk ruang yang luas dan nyaman sehingga bahan bangunan yang di pakai dalam bangunan Rusun Pekerja Migas ini menggunakan bahan yang lembut, ringan dan kuat, sehingga pemakai bangunan merasa nyaman dan tenang di dalam bangunan.

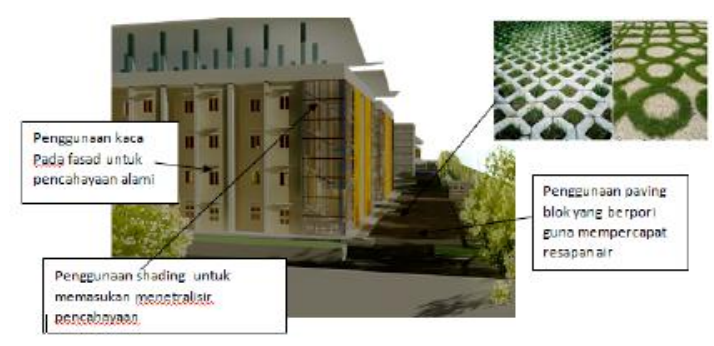

Gambar 20. Konsep Sistem Bahan Bangunan

\subsection{Hasil Perancangan Rusun Pekerja Migas}

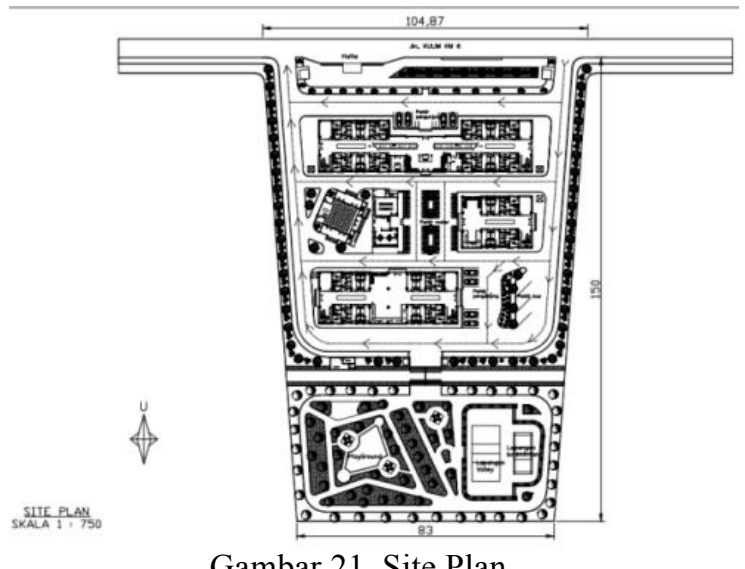

Gambar 21. Site Plan

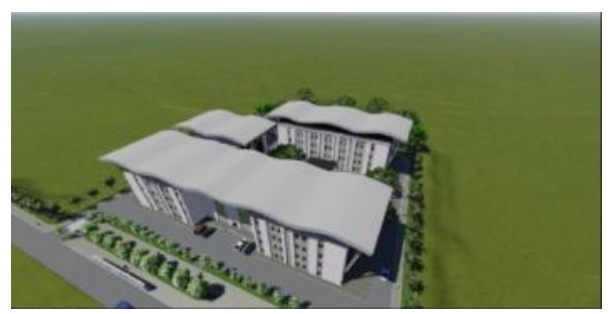

Gambar 22 Site 3D

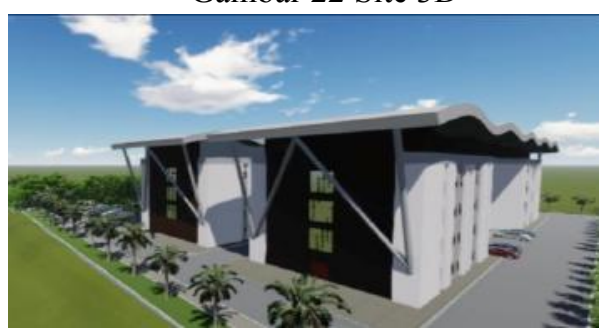

Gambar 23. Perspektif 3D 


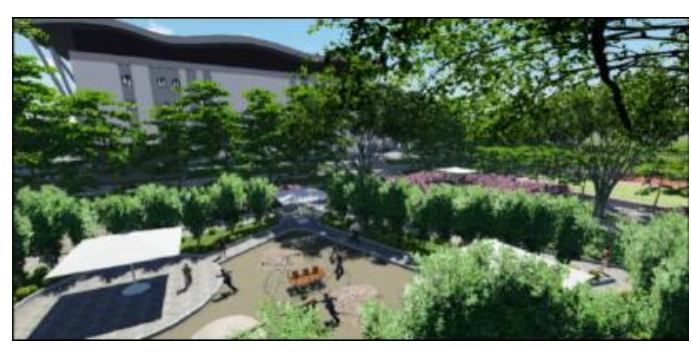

Gambar 24. Perspektif 3D Taman

\section{KESIMPULAN DAN SARAN}

Berdasarkan perencanaan pembangunan Rusun Pekerja Migas ini maka kesimpulan yang dapat diambil adalah sebagai berikut:

1. Kota Duri sebagai Kota Industri Minyak terbesar di Asia Tenggara yang menimbulkan perkembangan kota pada kegiatan pembangunan, perdagangan dan industri. Dalam hal ini, memicu terjadinya urbanisasi dan terjadi kepadatan penduduk. Salah satunya di daerah Kota Duri yang kurangnya unit hunian layak untuk para pekerja buruh di industrial migas.

2. Perancangan Rusun Pekerja Migas di lakukan sebagai alternatif hunian bagi pekerja yang dapat memberikan kesejahteraan kehidupan masing-masing personal. Oleh karena itu perancangan ini menggunakan tema perilaku yang di titikberatkan pada konsep behaviorisme.

3. Dengan menggunakan standard an teori perancangan rumah susun dan di dukung teori tema dan konsep behaviorisme maka di harapkan perancangan dapat menampung kegiatan pengguna berdasarkan tapak yang telah di gunakan.

4. Konsep ini diharapkan dapat memenuhi kebutuhan bagi masing-masing pengguna yang memberikan fasilitas-fasilitas pada bangunan pada masyarakat sekitar. Namun, penerapan tema dan konsep ini dapat memberikan dampak positif juga bagi pengguna bangunan sekitar,

\section{DAFTAR PUSTAKA}

1. Pustaka Buku

Neufert, Ernest, 1989, DataArsitekJILID2

Edisi2. PenerbitErlangga, Jakarta.
Neufert, Ernest,

1996 , DataArsitekJILIDIEdisi 31. Penerbit Erlangga, Jakarta.

Neufert, Ernest. 2002, Data ArsitekJilid 2Edisi 33. Penerbit Erlangga, Jakarta.

Ching,D.K, Francis.1985, Arsitektur : Bentuk, Ruang\&Tatanan. PenerbitErlangga, Jakarta.

Ching,D.K, Francis dan Cassandra Adams, 1985, Ilustrasi Kontruksi Bangunan, Penerbit Erlangga, Jakarta.

Panero, J dan Martin Zelnik. 2003, Dimensi Manusia dan Ruang Interior. Penerbit Erlangga, Jakarta.

Jhon, Geraint \& Herad, Helen. 1981, Handbook of Sports and Recreational Building Design Volume II : Indoor sports.London: The Architectural Press.

Brophy and Smith,1997, Pengembangan Rumah Susun dengan konsep Mixed-use dan mixed-income, , hal 5.

\section{Pustaka Internet}

https://id.wikipedia.org/wiki/Rumah_susun https://kriandianti.wordpress.com/2015/06/1 1/rumah-susun-dasar-hukum-pengertiandan-macam-rumah-susun/ https://sites.google.com/site/arkideaproperty/ input/info-rumah-susun/definisi-rumah$\underline{\text { susun }}$ https://data.go.id/dataset/rumah-susunsederhana-menurut-lokasi-luas-tipe-dankota-adm-dki-jakarta 